\title{
Encouraging Responsibility of Teenage Girls in Online Social Networks Through Changes in the Activities of Children's Day Centre Specialists
}

Lilia Žukauskienè $\dot{e}^{1}$ Ilona Klanienè ${ }^{2}$, Rasa Skališiene $\dot{e}^{3}$

1 Klaipeda University, Faculty of Social Sciences and Humanities, Department of Pedagogy, S. Neries g. 5, LT-92227 Klaipèda, Lithuania, lilia.zukauskiene@gmail.com

2 Klaipeda University, Faculty of Social Sciences and Humanities, Department of Pedagogy, S. Neries g. 5, LT-92227 Klaipèda, Lithuania ilona.klaniene@ku.lt

3 Klaipeda University, Faculty of Social Sciences and Humanities, Department of Pedagogy, S. Neries g. 5, LT-92227 Klaipeda, Lithuania, rasa.jokubaite@gmail.com

Annotation. The article presents the results of research on the changes in the activities of specialists from the Children's Day Centre (CDC) in order to achieve the responsibility of teenage girls in online social networks. The qualitative research is based on the methodology of the grounded theory, A. Strauss \& J. Corbin (1990) version. The research highlighted the following changes in the activities of professionals: support and involvement of girls' parents in CDC activities, its activity reflection, creativity in activating girls' responsible participation in OSN, and lifelong learning.

Keywords: Children's Day Centre (CDC), Children's Day Centre specialists (social workers and social educators), activity changes, teenage girls, responsibility in online social networks.

\section{Introduction}

Research over the last decade reveals that the Internet and social networks are becoming especially important in the lives of teenagers, who often spend most or even all of their time there, using smart technologies to connect these networks (Grigutyte், Pakalniškiené, Raižienė \& Povilaitis, 2018; Anderson \& Jiang, 2018; Helsper \& Smahel, 
2020; O'Reilly \& Levine, 2020). A comparative analysis of the use of the Internet by Lithuanian children in 2010 and 2018, carried out by N. Grigutytè et al. (2018), revealed the increasing availability and accessibility of the Internet, but at the same time areater possibility to experience certain threats. When participating in online social networks (hereinafter - OSN), young people often face various risks (Grigutytè, Pakalniškienè \& Raižiene, 2019) that endanger their safety.

The most common threats on the Internet are: misinformation, not corresponding to adolescents' communication level, dissemination of information, harassment and bullying (O'Reilly et al., 2020). In addition, cyberbullying (disclosure of personal information, watching pornographic and aggressive content, receiving unacceptable text messages with sexual content, etc.), which causes painful consequences for children (Grigutytè, et al., 2019), and sharing explicit photos in order to obtain a positive evaluation (Paluckaitė \& Žardeckaitè-Matulaitiené, 2019). Risky behaviour, as a phenomenon typical to adolescence, increases the likelihood of exposure to hazards and risks that are greater at this stage of life (O’Reilly et al., 2020). An ability to critically assess risk situations is not yet fully developed in adolescence, therefore young people are particularly vulnerable at this age (Steijn, 2014; Schilder, Marjolein, Brusselaers \& Bogaerts, 2016).

The problem of responsible behaviour on the OSN is particularly relevant for those teenage girls who grow up in families at social risk, and who lack various means of support and education from their social environment. Social risk can be a variety of factors and circumstances that cause families or individuals to experience social exclusion: a lack or absence of social skills of adult family members to properly care for and educate their (adopted) adolescent children; a failure to ensure the full physical, mental, spiritual, and moral development, along with the safety conditions of their (adopted) children in a family $<\ldots$. > vagrancy, homelessness; and a lack or absence of motivation to participate in the labour market (Lietuvos Respublikos socialiniu paslaugu i istatymo Nr. X-493 1, 2, 3 straipsniu pakeitimo ir istatymo papildymo 5 straipsniu ir priedu įstatymas, 2021, 2 straipsnio pakeitimas, 7 dalis).

It is observed that girls spend more time communicating on OSN social networks than boys, and therefore their communication on OSN can often lead to greater vulnerability regarding aspects such as harassment, bullying, exploitation, sexual persecution, and seduction (Dowdell \& Bradley, 2010). Girls are more likely to post explicit photos on social networks (Ramsey \& Horan, 2018; Paluckaite et al., 2019), and they more often share information about their daily activities with others (Wiliams \& Merten, 2009).

N. Steinfeld (2020), M. O'Reilly et al., (2020) note that contemporary adolescents are active users of social networks, therefore their personal responsibility in online activities is necessary, and a need for pedagogical assistance to promote it becomes apparent. G. Čiapienè \& G. Sudniute (2020), who researched the school context, emphasized that pedagogical activities, methodologies or digital teaching tools and forms intended for a 
safer Internet must be changed, and that only focused cooperation can enable children to feel safe on the Internet and to use technologies responsibly.

Responsibility is a measure of active honesty: in a social sense, it determines passive, and in a moral, active integrity. Responsibility as an incentive for active honesty orients a child to the needs of other people, their problems, and their help in solving them; the norms of passive honesty emphasize the actions that are not allowed for an honest person (Bitinas, 2013, p.150). Responsibility of teenage girls regarding OSN is associated with their safety in a virtual environment (Shilder et al., 2016; Steinfeld, 2020; O'Reilly et al., 2020; etc.). Research has revealed that safe use of OSN requires personal responsibility of children and youth (Schilder et al., 2016; O'Reilly et al, 2020), which is based not only on knowledge but also on capabilities and values (Cassells, Gilleran, Morvan \& Scimeca, 2016, p. 13).

After analysing the issue of teenage girls' responsibility in social media, M. O'Reilly et al. (2020) revealed that adolescent girls recognize the importance of responsibility and point out the lack of responsibility as a decisive factor of inappropriate behaviour on social media. The development of strategies for active participation of teenage girls in decision-making in order to become responsible and conscious social media users (how they present themselves in cyberspace, how they communicate with others, what verbal and visual content they share, and how they behave when they face threats etc.) are emphasised in further research (Helsper et al., 2020) (O'Reilly et al., 2020).

Scientific research (Steinfeld, 2020; Jusienė, Laurinaitytė \& Pakalniškienė, 2020; etc.) reveals that adolescents who live in disharmonious and/or one-parent families often lack parental support and social skills, so their participation in OSN is more often characterised by higher risk expression as well as the need for support for responsible online activities.

In Lithuania, children from families at risk can receive assistance from Children's Day Centres (hereinafter - CDC), which not only provide social services but also organise children's education (LR socialinés apsaugos ir darbo ministro įsakymas „Dèl Akredituotos vaikų dienos socialinès priežiūros teikimo reikalavimų ir rekomendacijų patvirtinimo“, 2020). CDC activities are carried out with specific entities and have specific goals: 1) to solve children's social problems, and to organise their education and informal employment by ensuring social work with parents; 2) to create conditions for the socialization and early prevention of children in criminal activities, and to provide social services to families at social risk (Grudulaite, 2016). CDC educational activities aim at social participation and empowerment of a family, cooperation with a family, and inter-institutional cooperation (Buzaitytė-Kašalynienė \& Liaudginaitė-Zamalienė, 2012). The content of the activities of CDC specialists (social workers and social educators) includes the development of children's social and life skills, socio-cultural education, protection of their rights, and integration into a family and society; information, consultancy, and mediation services; organisation of children's leisure activities; development and maintenance of bond with schools, non-governmental organizations and other institutions. CDC specialists can 
carry out children's social integration, prevention and other programmes, organise project and/or voluntary activities (Lietuvos Respublikos socialinės apsaugos ir darbo ministro issakymas „Dèl Akredituotos vaikų dienos socialinès priežiūros teikimo reikalavimų ir rekomendacijų patvirtinimo“, 2020, II sk.).

CDC are institutions that take care not only of children from at-risk families, but they also contribute to children's prosocial development. In skills development activities, organized by CDC, children learn dialogue, cooperation, creativity, responsibility, decision-making, reflection on experience, acceptance and provision of assistance to another person, and also develop an ability to recognize and express feelings and thoughts (Liepinskaitė \& Motečienè, 2017).

The opportunities of educational assistance for teenage girls from at-risk families attending CDC are limited, therefore, a change in the activities of the centre's specialists in order to achieve their responsibility in OSN becomes significant, while creating a model of responsible behaviour in virtual spaces for teenage girls. One of the activities of CDC specialists is the identification of problems among teenage girls regarding their actions on OSN, as well as monitoring and adjusting their behaviour on OSN.

The scientific issue is formulated by a question: how are the activities of the CDC specialists changing in order to achieve the responsibility of teenage girls in OSN? The aim of the research is to deepen the understanding of the changes in the activities of CDC specialists in order to ensure the responsible performance of teenage girls in OSN. The goals of the research: 1) to reveal the causes that encourage CDC specialists to change their activities in order to make teenage girls responsible in OSN; 2) to distinguish contextual and intervening factors that determine changes in the specialists' activities; 3 ) to highlight CDC specialists' action strategies regarding responsibility of teenage girls in OSN; 4) to identify the consequences of changes in the activities of CDC specialists in pursuit of responsibility of teenage girls in OSN.

\section{Research methodology}

The research is based on the version of grounded theory as a qualitative research methodology by A. Strauss \& J. Corbin (1990). The research enables answers to the question of how a certain phenomenon takes place, and raises the question of why it manifests itself in one way or another. The research aims to understand better an existing, but little researched, social phenomenon of the changes in the activities of CDC specialists regarding responsibility of teenage girls in OSN. While examining this social phenomenon, summaries and conclusions are presented referring to the empirical data and rejecting preconceived hypotheses (Corbin \& Strauss, 2008; Strauss et al., 1990). The research aims to distinguish the ideas from empirical data regarding the little-researched activities of CDC specialists while pursuing responsibility among teenage girls in OSN. 
This methodological approach was chosen for the presentation of a systematic analysis of research data (revealing the causes, context, conditions, action strategies, and consequences of the phenomenon) (Corbin et al., 2008).

In order not to seek to form a representative sample solely on the basis of representativeness, a targeted selection of respondents was performed in the research, (Strauss et al., 1990). The sample was designed to include the largest possible territory of Lithuania, therefore 14 specialists from CDC in Vilnius, Kaunas, Klaipèda, Mažeikiai, Telšiai, Šiauliai, and Skuodas towns and districts participated in the research. The socio-demographic characteristics of the research participants was: 13 women and 1 man participated; 7 social workers, 2 of whom held a position of CDC manager with work experience from 4 to 25 years; and 7 social educators with work experience from 1 to 12 years. The selection of research participants was carried out in order that each new case provided additional recent information on the subject matter. Those professionals having at least one year of work experience with adolescents - and preferably with teenage girls who had encountered problems with OSN - participated in the research.

The research data was obtained from semi-structured interviews, analytical or interpretive procedures. These are considered appropriate for understanding the meanings expressed by CDC specialists about changes in their performance due to the responsibility of teenage girls in OSN regarding problems of their actions on OSN, and responsibility in OSN.

The interviews provided an opportunity to look at the phenomenon of changes in CDC activities through the eyes of specialists, their subjective experience and language.

The analysis of the research data was performed in accordance with the provision that it is important to explore deeply the reflections of the practical activities of the research participants, to reveal their meanings and make them visible to all readers (Žydžiūnaitè, 2016, 2019). According to J. Corbin et al. (2008), in order to develop the underlying theory, the data analysis was performed in three stages: open coding, axial coding, and selective coding. The analysis of the data obtained from this research took place in two stages: open coding and axial coding (Corbin et al., 2008). In the first stage, the interview text was transcribed, paraphrased, conceptualized, and categorized in order to give precision and specificity to the concepts, and then comparisons and questioning were performed. In the second stage, the relationships between the categories were established, and by applying a paradigmatic cause-and-effect model, an analysis was performed (Corbin, et al., 2008). At this stage, causes, context, conditions, action strategies and consequences of the changes in the activities of the CDC specialists in pursuit of responsibility of teenage girls in OSN were highlighted. The aim of this research was not to develop an grounded theory, so the third stage - selective coding - was not performed.

While analysing the research data, attention was paid to the following semantic aspects: causal conditions that promote the emergence and development of the phenomenon; the context in which actions and interactions, relevant to the realization of 
the phenomenon, take place; intervening conditions (supporting and restricting certain actions) that affect actions and interactions; action/interaction strategies that enable to manage an existing phenomenon; consequences or results of interactions that relate to people, place, or subject (Strauss et al., 1990).

\section{Research results}

The phenomenon that emerged during the axial coding phase was given the name "Changes in the Activity of the Specialists", which is illustrated in the sayings of the research participants (in vivo): "to help, not to forbid". The development of this phenomenon is revealed referring to the paradigmatic cause-and-effect model (Corbin et al., 2008). While dealing with the first goal - to reveal the causes that motivate CDC specialists to change their activities in order to make teenage girls responsible in OSN - it was revealed that the emergence of a phenomenon "changes in the activities of specialists" "to help, not to forbid" is caused by the following reasons: anxiety because of too much freedom and irresponsible behaviour of teenage girls on OSN; non-compliance with the rules; parental involvement only when a problem arises; and security on OSN - a concern of adults.

Anxiety about freedom on OSN. The specialists believe that teenagers want freedom and autonomy on OSN, they seek independence, establishment, recognition, and they oppose the imposed demands of adults, and act irresponsibly: "Teenage girls want freedom, but do not know how to deal with it, they resist, this freedom is worrying them, there are no barriers, it cannot be banned" (10th informant); "Teenage girls want to operate on OSN freely, however, they lack responsibility regarding security, which is what I am worried about" (7th informant ). CDC specialists are looking for ways to help girls behave safely on OSN: "The usual things don't work here, we're faced with the challenge of finding effective ways to help girls behave safely on OSN" (10th informant). Specialists understand that banning access makes it difficult to achieve the desired results, therefore it is necessary to look for other ways to teach girls to understand the relationship between freedom and responsibility, and consequently to evaluate their actions on OSN, not referring to externally imposed requirements.

Failure to follow the rules. CDC specialists acknowledge that banning teenagers from using OSN or the Internet in general often provokes a variety of reactions: "Younger girls wave warnings aside"; "After listening to warnings, elder ones do the same again" (10th informant). Although specialists apply certain CDC rules for using the Internet in their activities, they face resistance: "we are trying to introduce such a rule and fight with non-compliance, because teenagers are challenging boundaries" (11th informant). Teenage girls are more likely to disregard the rules than younger children: "it is easier to agree on rules with the younger ones for using mobile phones, but teenage girls tend to simulate and cheat" (6th informant). Specialists noticed a desire to be independent in 
girls, and an intentional resistance to bans: "independence is very important for teenagers, if you try not to allow something, they will do the opposite" (14th informant). So, one of the reasons that encourages CDC professionals to change their activities is that the applicable rules regarding OSN are not effective, teenage girls oppose them, and find ways to circumvent them.

Parental involvement only when a problem arises. Despite the efforts of the specialists to involve parents in CDC life, parents' involvement in the activities of teenage girls is more episodic, and they often only pay attention to their child's activities on OSN when problems arise: "Parents began to observe their daughter after they realised she was not attending school and was dating strangers from the Internet" (6th informant). Other specialists noticed that "parents are often too late in paying attention to what teenage girls are doing on OSN, and the latter turn to them only when they lose their facebook profile page or encounter cases of long-term bullying" (14th informant). Changes in the activities of the specialists with teenage girls and parents are driven by the latter approaching them only when there is a problem with girls acting on OSN.

Security on OSN - adults' concern. According to the specialists, in the process of helping teenage girls, it is important to realize that decisions about responsible behaviour regarding OSN are made by the CDC professionals and other adults that are directly involved with their child: "It is important to have an adult's shoulder to lean on at any time" (14th informant). Specialists consider that the contribution of adults to the responsible participation of girls in OSN is significant and must be based on care, support and compassion.

The second goal was to distinguish the contextual and intervening factors that determine the changes in the activities of specialists. The context or the conditions of a phenomenon under which actions and interactions take place are important for its realization and response to it (Strauss et al., 1990). Changes in the activities of the CDC specialists with girls in order to make them responsible in OSN are determined by four contextual conditions: a virtual space - available everywhere; a need for continuous education; different experiences of CDC; and activities without prejudice regarding OSN.

Virtual space - available everywhere. On the one hand, the specialists do not doubt the attractiveness of cyberspace, but on the other hand its anonymity prevents them from seeing unsafe behaviour of adolescents and from anticipating necessary activities: "girls have phones, we can't protect or see what they do with them, the Internet isn't limited" (13th informant) "they use the Internet both at home and in public libraries, and there is no control over them, it's scary what can happen" (7th informant). Specialists consider the relationship between respect for girls' space and interference with it: "to what extent must a girl's space be respected, how can it be entered so that nothing bad happens, whilst acknowledging that freedom must also be given" (1st informant).

A need for continuous education. The specialists emphasize that educational activities carried out by $\mathrm{CDC}$ are not a single day process, that they require constant efforts: 
"It takes place year after year, it is everyday life, development, discussion of situations, conversations, they come to talk about what was going on online, what has happened every day, the girls tell us everything" (9th informant). In order to ensure the safety of girls on OSN, the specialists emphasize the importance of systematic activities: "CDC needs to conduct regular, systematic sessions with teenage girls on risky online behaviour and safety" (13th informant). Thus, in order to achieve the responsibility of girls in OSN, a need for its continuity and systematicity in the educational activities of the CDC specialists becomes apparent.

CDC - different experiences. CDC allows the specialists to take into account the individual needs of girls and their parents in their activities: "we are not school, we have different children, with different experiences, development levels, capabilities, and we work with each of them individually and together; in one case it can take months to solve the problem, in another, a one-time intervention is enough; one child can sit down for the whole session, the other is able to focus for only five minutes" (10th informant); "There are no universal ways to help girls, an individual approach must be found for each" (7th informant). In this context, the individualisation of the professionals' work with the girls and their parents is also significant: "when organizing activities for parents regarding child safety on OSN, it is important to take into account the children's age and level of understanding, which are different" (11th informant). Individual work with girls and their parents enables the latter to better understand the benefits of responsible participation in OSN, not only here and now, but also in the future.

Activities without prejudice against OSN. Negative attitudes towards the participation of young girls in OSN condemns them beforehand, which may not only increase their curiosity regarding OSN, but also lead to their rudeness and distancing: "One woman wrote that all girls on Facebook are already potential victims of prostitution, that means that if such a person came to work in CDC with such an attitude, they would not achieve much" (9th informant). Specialists acknowledge the prevailing personal prejudice against OSN: "I don't want to post on Facebook, I have neither the time nor the desire, and no one whom to show everything there" (9th informant); however, they realize that their personal position and participation in OSN is an important factor in teenage girls education: "well, if they always react negatively, then later on teenage girls stop telling anything, as they see that you either do not understand, or do not want or need to know" (12th informant). Specialists understand what it is that can hinder their interest in teenage girls' activities on OSN: "without Facebook it is more difficult to monitor teenage girls' activities, but I try, I am interested, it is necessary for a specialist to know the issues of teenage girls' lives, to understand the role of OSN" (6th informant). CDC specialists see that prejudice against OSN hinder positive educational activities with girls by promoting their responsibility in cyberspace. 
The broader structural context of the phenomenon, which influences actions and interactions, has been revealed by such intervening conditions as teenage rebellion, different CDC attitudes on the topic of OSN, and limited resources.

Rebellion of teenage girls. Specialists note that teenage girls have a desire to get to know themselves, but searching for thier own identity often encourages rebellion against adult actions, warnings, or suggestions: "it is difficult to talk to teenage girls because their age is a rebellious age, when negative attitude towards adult authority, and a desire to be independent, prevail" (8th informant). Protesting against rules, norms and control happens in a variety of permissible and impermissible ways, and it gives professionals an impression that it is a real emotional confusion: "they hear information, but it does not last long" (6th informant), specialists feel frustrated that teenagers do not appreciate the assistance provided: "It is disappointing when, after a colleague's training sessions, handouts end up in the rubbish bin" (7th informant). Specialists' perceptions of teenage girls' specific rebellion to adult norms and rules encourage the search for more effective ways of promoting responsibility on OSN.

Different CDC positions on OSN topic. Another intrusive condition is that not all CDC leaders recognize the need for OSN activities. According to the specialists, some of them are more focused on the development of children's self-expression, others on other activities: "some are more focused on the development of teenage girls' self-expression, others on their socialization, the rest on employment in general" (1st informant). It is acknowledged that there is a lack of communication between the leaders and the specialists in the activities with teenage girls in dealing with responsiblity on OSN, there is not always a consensus in recognizing the importance of tackling this problem: "As a leader, I could say that not all leaders understand the importance of this problem, and because of a heavy workload, we sometimes may not assess certain things" (11th informant). Although not all CDC leaders prioritize OSN, specialists themselves are looking for opportunities for activities that promote girls' responsibility in OSN.

Limited resources. Although specialists acknowledge that the CDC environment is favourable to girls' education, they point out restrictive conditions on the topic of OSN activities. A lack of CDC specialists limits the opportunities to perform all planned OSN activities, and not enough time for that: " $\mathrm{CDC}$ is limited to perform the most basic tasks, it lacks human resources: I can only look after them so that they behave" (1st informant). $\mathrm{CDC}$, as non-governmental organizations, survive on project funds, and difficulties arise when projects are not approved or when the project evaluation process takes time, and there are simply no CDC funds for activities: "there is a need to teach teenage girls to perform safely on OSN, but unapproved project funding does not allow these activities to be carried out" (3rd informant). Thus, the restrictive conditions on the topic of OSN activities are a lack of time, and insufficient human and financial resources. However, 
at the same time these obstacles can become an incentive for the CDC professionals to change their activities.

While dealing with the third goal of the research, it became clear that strategies for action and interaction aimed at the responsibility of teenage girls in OSN are important for the development of the phenomenon of changes in the activities of CDC specialists: parental support, reflexion of activities, experiantial learning, options/alternatives of actions on OSN, and creativity in activities.

Parental support is one of the strategies of change in the specialists' activities. According to the specialists, parents often feel uncomfortable when participating in CDC activities, they do not want to show their lack of skills, and often are afraid to speak or say something wrong etc. In order to change the feelings of parents in a positive direction, specialists expressed their understanding and support: "we realized that a mother felt uncomfortable while doing a task, but we turned the situation around so that an older daughter would help her mother to finish the task and they then got along well" (3rd informant); "In order to help both a family and a child, it is important to earn the family's trust in order to make them feel that you really want to understand and help them, and to not extract information about what is wrong with their family and pass it on to the responsible authorities" (10th informant). Parental support helps to strengthen self-confidence, responsibility for overcoming childish problems, and to believe that CDC specialists want to help rather than do harm.

Reflection of activities. Two aspects emerged from this action/interaction strategy: 1) self-reflection of the CDC specialists on the topic of OSN activities; 2) encouragement of girls to reflect on their actions on OSN.

Firstly, specialists seek to consider and evaluate their activities on the topic of OSN activities: "it is important to analyse and evaluate the activities on OSN; when I first created a Facebook profile I didn't know how to behave, now I realise that I would have behaved differently, but such experience only comes with time" (2nd informant). Specialists recognize that the topic of OSN is a new one and that it poses considerable challenges for activities, reflecting on how they should change and develop to help teenage girls cope with the challenges on OSN: "we need to learn from each other by evaluating our activities and those of our colleagues, we need to be aware of sensitive areas in order to improve and find solutions" (7th informant). Monitoring one's activities, careful analysis, reflection and evaluation, and discussions with colleagues enable specialists to identify strengths and/or weaknesses of their work on OSN, and to anticipate the possibilities of useful change. Another aspect of this action/interaction strategy is encouraging girls to reflect on their activities on OSN. Specialists explain that sometimes it is appropriate to look at the situation from a distance, through the eyes of others, distancing oneself from emotions, asking yourself what you are doing, whether you are doing it right, what you can do differently. Secondly, to set examples to teenage girls that analysing and reflecting on their actions on OSN are important for a responsible and safe performance: "to teach 
teenage girls to analyse their actions, choices, and to understand why they behave like this in one situation or another, what is the purpose of such behaviour, what the consequences might be, and to teach them to reflect on their activities on OSN" (14th informant). The encouragement of girls to reflect and evaluate their behaviour on OSN enables them to strengthen their personality traits, something that is necessary in other life situations as well.

Experiential learning on the topic of OSN is described by the specialists as an effective one: "experiential learning operates through experience and their own active participation, situational awareness, discovery and perception of new things, and most importantly, analysis and reflection on these discoveries and perceptions" (14th informant). According to the specialists, it is useful for girls to analyse cases/situations of participation in OSN, discuss them, and to accumulate positive experiences: "the analysis of specific cases in the group is justified, for example, we had a case from the media, where a girl was raped and killed after meeting a stranger from the Internet. The girls were very involved, there were a lot of discussions, and we were looking for solutions on how to behave" (7th informant). Experiential learning gives teenage girls an opportunity to empathize with the situation, evaluate their own experiences, search within a group and to find real solutions useful not only in a virtual environment, but also in reality.

Options/alternatives of actions on OSN. According to the CDC specialists, it is appropriate to disclose and convince teenage girls that they always have a choice when acting on OSN. According to the experts, teenage girls often view the situation or their actions on OSN from a narrow angle, so they need to be taught to look at the situation from different angles in order to see more than one action/ solution: "we discuss their actions, and during the conversation girls find answers to how they could act differently, and how they could do otherwise" (9th informant). By revealing behavioural choices in the virtual environment, girls are encouraged to consider the positive and negative aspects of their actions on OSN and to make decisions: "to realize that each of their actions is at a crossroads, and only they can decide which way to go" (13th informant).

Creativity in activities. In order to be effective in work with teenage girls on the topic of responsibility in OSN, the specialists see the importance of creativity: "a certain message and information must be communicated to adolescents creatively" (3rd informant); "Their abilities are effectively enhanced by creatively adapted play elements, and simulation games" (5th informant). According to the CDC specialists, teenage girls benefit from participation in preventive events and campaigns: "we participate in a campaign 'Without bullying', teenage girls learn more about how to avoid email bullying, where to turn to in such cases, etc." (12th informant); "Implementation of projects regarding online responsibility, and participation in social campaigns" (1st informant). The creativity of professionals in their activities, involving teenage girls in games and online safety prevention events, creates the conditions for strengthening their responsibility in OSN. 
The fourth goal of the research is to identify the consequences of changes in the activities of CDC specialists in achieving teenage girls' responsibility in OSN. Consequences or outcomes of interactions that relate to people, place or subject can be actual and potential (Strauss et al., 1990). Action and interaction strategies of the CDC specialists highlighted the following consequences: feedback, community concentration, and lifelong learning of specialists.

Feedback. The specialists note that they receive positive feedback from parents about their activities with teenage girls on the topic of OSN, as well as about changes in girls' behaviour: "after talking to parents, a girl denies everything and 'blocks', but later positive changes are observed" (1st informant); "A mother reported that her daughter spends less time on the computer now, since she started attending CDC" (4th informant). After joining a group of Facebook friends of one teenage girl, the specialist started to observe positive changes in the girl's online behaviour: "adding a girl to her friends list on Facebook after she had been told that the profile content should be positive, there were obvious changes in her OSN behaviour" (7th informant). According to the specialists, trust in parents, and empathy for their condition produce positive results, encourage family members to become more actively involved in CDC life, thus enabling working with girls more effective due to their responsibility in OSN. It also increases mutual understanding: "it seems that sometimes a warm conversation, listening and not condemning, is needed, and a family reveal themselves in a completely different way, it seems they hear you, and have a desire to behave differently, maybe sometimes we lack belief in a family" (8th informant). The received feedback strengthens the motivation of professionals to seek new ways of promoting responsibility of teenage girls in OSN.

Community concentration. As a result of their activities with teenage girls, specialists feel stronger support from the local community, the purpose of the CDC is more widely revealed and is more involved in its activities, which encourages a different approach to the institution, and reveals a higher diversity of activities: "sometimes it seems that we lack ideas or we start repeating, a person from a local community comes and offers something, new ideas reappear, you see everything differently, you start working again" (13th informant). When working with girls on the topic of responsibility in OSN, cooperation with other professionals becomes significant. A new person who enters the CDC environment brings some fresh air, and this has a positive effect on the teenage girls: "information from other professionals reaches children differently, they are already very used to us, sometimes it has little effect" (5th informant); "One person cannot know everything, so cooperation with competent specialists from other organizations is important" (4th informant). The involvement of local (where CDC performs) communities, as well as cooperation with specialists, responsible for the child's well-being, from other institutions is positively changing the activities of CDC specialists in the field of responsibility of teenage girls in OSN. 
Life-long learning of specialists. Specialists are quite critical with regard to their work with teenage girls on the topic of responsibility in OSN: "CDC specialists are not fully prepared to advise teenage girls on the threats and security of OSN. When it comes to girls' security on OSN, it requires professional knowledge, skills that are still lacking" (10th informant); some do not keep up with current innovations which sometimes makes teenagers feel uncomfortable: "not knowing everything about OSN makes you feel uncomfortable with teenagers, just not keeping up with current innovations" (2nd informant); "I would like to be more prepared to educate teenage girls regarding OSN security, as this topic is relevant and sensitive for contemporary adolescents" (7th informant). However, specialists revealed their aim to improve the responsibility of adolescents in OSN: "trainings for social pedagogues and social workers are needed; if this happened, the dissemination of information on OSN would make more sense" (11th informant); "I have heard that there are trainings at schools on safe participation in OSN, but trainings for CDC professionals on similar topics would be very beneficial, as our visitors are a specific audience, very vulnerable and sensitive to threats on OSN" (14th informant); "A lot of knowledge is needed to influence girls to change both their thinking and their actions on OSN"(11th informant); "A realization comes that you need to strengthen your skills to give something, and for this, you have to start from yourself first" (4th informant). A need for lifelong learning, identified by CDC specialists, is one of the most important conditions for the formation of responsible behaviour of girls on OSN.

\section{Discussion}

The results of our research revealed that anxiety about the desire of teenage girls' to operate freely on OSN, Internet access, and disregard for existing rules at CDC, encourage specialists to change their activities with teenage girls. These results respond to N. Grigutyte et al. (2018) research findings on an increasing availability of the Internet, which may increasingly expose children to a variety of threats. The experiences of the specialists who participated in the research, revealed that the activities of the CDC usually meet social, learning and other needs of teenage girls, but it also noticed a need for continuity and a systematic approach to activities in order to achieve responsibility of girls' in OSN. These research results respond to the thoughts of N. Steinfeld (2020), M. O'Reilly et al. (2020) regarding teenage girls' personal responsibility in online activities, as well as G. Čiapienè et al. (2020) observations on the importance of change of pedagogical assistance in teaching children to use technologies responsibly.

In the research, the rebellious nature of teenage girls, the priorities of different CDC activities, and limited CDC resources emerged as disruptions, but also as factors encouraging specialists to find ways to educate teenage girls on the topic of responsibility in OSN (implementation of projects, participation in social actions, etc.). Changes in the 
activities of the CDC specialists were evident through parental support and involvement into CDC life, self-reflection of their activities, and encouragement of girls to reflect on their actions on OSN, learning from their experience, and creativity of specialists by activating teenage girls. Other authors (Helsper et al., 2020; Cassells et al., 2016) also emphasize the active participation of teenage girls in decision-making regarding OSN.

The creativity of CDC specialists, involving teenagers in games and online safety prevention events, creates preconditions for strengthening their responsibility in OSN, which responds to the statements of other researchers (Liepinskaite et al., 2017) regarding skill development activities organized by CDC, which enable children to learn cooperation, responsibility, decision making, and reflection on experience. The activities of CDC specialists, which aim to make adolescent girls responsible in OSN, are changing from bans to open and trust-based relationships. Specialists receive encouraging feedback from parents and girls about positive behavioural changes of teenage girls on OSN, which in turn helps them to focus more on parental support and local community involvement, and cooperation with specialists from other institutions. In addition there are signs of mentoring in the activities of specialists. Other researchers (Grudulaite, 2016) also emphasize the CDC goal to empower family, cooperate with it and other institutions, and emphasize the importance of the role of parents in the online activities of children (Steinfeld, 2020).

Limitation of the research. To address the issue of adolescent girls' responsible behaviour on OSN, interviews were conducted with CDC specialists, and their own assessment of changes in their activity could be supplemented by interviews with adolescent girls and their parents.

\section{Conclusions}

CDC specialists are encouraged to change their activities with teenage girls due to the anxiety of the girls' desire to operate on OSN too freely, but insecurely and irresponsibly, disregarding the existing rules for using the Internet, and intentional resistance towards them. Another reason is an occasional involvement of parents in the activities of the $\mathrm{CDC}$ or the request for help only in the case of a problem with OSN. The activities of the CDC usually take place in response to the social, educational and other needs of the girls, but the experiences of the professionals involved in the study highlighted the need for continuous and systematic activities to achieve responsibility of the girls in OSN.

The changes in the activities of CDC specialists with girls in order to make them responsible with OSN are determined by such contextual conditions as an availability of virtual space, different experiences of girls, lack of preconceptions of specialists regarding OSN, all of which hinder educational activities. The anonymity of OSN prevents professionals from identifying any unsafe behaviour of the girls and anticipating 
necessary preventive actions. The rebellious nature of teenage girls towards specialists' warnings and/or suggestions for responsible behaviour on OSN, disagreement between CDC managers and professionals in recognizing the importance of tackling the issue of teenage girls' responsibility in OSN, a lack of specialists (human resources), and CDC project funding (long lasting process), are all limiting conditions associated with OSN.

In order to make teenage girls responsible with OSN, CDC specialists take educational interaction strategies: support girls' parents and involve them into CDC life, reflect on their activities, promote experiential learning, and creatively reveal responsible OSN choices/alternatives for girls. The parents of the girls often feel uncomfortable in the activities organized by CDC, do not want to show their lack of skills, and so in order to change the feeling of parents, professionals express their support to them. Observation, analysis, reflection and evaluation of specialists regarding their activities, and discussions with colleagues, help to identify the strengths and/or weaknesses of their work on the topic of OSN, and to purposefully anticipate changes in their activities. Specialists describe experiential learning as an effective activity that helps teenage girls to empathize with the situation regarding OSN. It also teaches them to evaluate their experiences, and to see and understand a number of alternatives to action/solution regarding OSN. Specialists creatively apply playful elements, simulation games, and encourage girls' participation in preventive events, and social actions, as well as CDC projects on the topic of online responsibility. The activities take a form of mentoring, responding to the girls' needs, knowledge, experience and values, with the aim of "helping, not prohibiting".

The research revealed the consequences of changes in the activities of CDC specialists in order to make teenage girls responsible with OSN: feedback, community mobilization, and continuous training of specialists. The positive feedback that professionals receive from parents helps them to realize that their activities are beneficial, and in turn this motivates further work with teenage girls to achieve their responsible participation in OSN. The gathering of the local community (where the CDC operates) manifests itself in two aspects: the purpose of the CDC becomes clear, a positive attitude towards this institution, and more opportunities for joint activities are revealed; by organizing activities in CDC, the members of the local community bring new ideas and experiences. Specialists would like to deepen and strengthen their knowledge, abilities and skills in order to achieve girls' responsibility in OSN, with one of the conditions of this being that they identify their need for lifelong learning.

Practical significance of the research results. The results of the research provide information for practical work with adolescents attending CDC. In addition, they serve in the development of OSN educational programmes for teenage girls in responsible participation, methodologies, providing guidelines for professional development and inter-institutional cooperation.

Based on the results of the research, several recommendations are formulated: to conduct research on the need for CDC educational activities, revealing the attitudes of 
teenage girls to participation in OSN, and their level of knowledge and skills; to focus educational activities on the most sensitive areas for girls, carefully selecting work methods and forms; to improve professional competence of CDC specialists, also their reflection, continuous learning, parental involvement, cooperation, and mentoring competencies; to constantly exchange ideas and insights in the field of OSN, and to carry out dissemination of their results among CDC specialists.

\section{Literature}

Anderson, M. \& Jiang, J. (2018). Teens, social media \& technology. Pew Research Center. Access online: http://www.pewinternet.org/2018/05/31/teens-social-media-technology-2018/

Bitinas, B. (2013). Rinktiniai edukologiniai raštai. III tomas: Hodegetika: auklejimo teorija ir technologijos. Vilnius: Lietuvos edukologijos universiteto leidykla [Selected educational papers. Volume III: Hodegetics: Theory and Technologies of Education. Vilnius: Lithuanian University of Educational Sciences Publishing House].

Buzaitytė-Kašalynienė, J. \& Liaudginaitė-Zamalienė, E. (2012). Vaikų dienos centrų tarpdalykinio bendradarbiavimo patirtis. STEPP: Socialine teorija, empirija, politika ir praktika, 6, 7-22 [Experience of interdisciplinary cooperation of Children's day care centers. STEPP: Social Theory, Empiricism, Policy and Practice, 6, 7-22].

Cassells, D., Gilleran, A., Morvan, G. \& Scimeca, S. (2016). Augantys skaitmeninès kartos piliečiai. „eTwinning" centrine paramos tarnyba [Growing citizens of the digital generation. eTwinning Central support service].

Corbin, J. \& Strauss, A. (2008). Basics of Qualitative Research. Techniques and Procedures for Developing Grounded Theory. California: Sage Publications.

Čiapienè, G. \& Sudniutè, G. (2020). Idèjos ugdymui: kaip atskleisti saugesnio interneto temas. Vilnius: Nacionalinè švietimo agentūra [Ideas for Education: How to reveal safer internet topics. Vilnius: National education agency].

Dowdell, E. B. \& Bradley, P. K. (2010). Risky internet behaviours: a case study of online and offline stalking. The journal of school nursing, 26(6), 432-443.

Grigutytè, N., Raižienè, S. \& Pakalniškienè, V. (2019). Vaikų (ne)dalyvavimas elektroninėse patyčiose ir emociniai bei elgesio sunkumai. Psichologija, 60, 72-85 [Children 's (non) participation in electronic bullying and emotional and behavioral difficulties. Psychology, 60, 72-85].

Grigutytė, N., Pakalniškienė, V., Raižienè, S. \& Povilaitis, R. (2018). Lietuvos vaikų naudojimosi internetu 2010 ir 2018 metais ypatumų palyginimas. Psichologija, 58, 57-71 [Comparison of features of Lithuanian children's usage of the Internet in 2010 and 2018. Psychology, 58, 57-71].

Grudulaite, L. (2016). The Perceptions of Children at a Children Day Care Centre about the Authority of a Social Worker. Acta Pedagogica Vilnensia, 36, 99-110. 
Helsper, E. J. \& Smahel, D. (2020). Excessive internet use by young Europeans: psychological vulnerability and digital literacy? Information, Communication \& Society, 23(9), 1255-1273. Access online: https://doi.org/10.1080/1369118X.2018.1563203

Jusienè R., Laurinaitytė I. \& Pakalniškienė V. (2020). The Psychosocial Factors of Elementary School-Aged Children's Compulsive Internet Use As Reported by Children and Parents. Prieiga per internetą: Psichologija, 61, 51-67 [The Psychosocial Factors of Elementary School-Aged Children's Compulsive Internet Use As Reported by Children and Parents. Internet access: Psychology, 61, 51-67].

Liepinskaite, I. \& Motečienė, R. (2017). Igalinančios socialinès paslaugos Vaikų dienos centruose: socialinių darbuotojų perspektyva. Socialinis darbas. Patirtis ir metodai, 20 (2), 29-53 [Enabling social services in Children's day centers: perspective of social workers. Social work. Experiences and methods, 20 (2), 29-53].

Lietuvos Respublikos socialiniu paslaugu istatymo Nr. X-493 1,2,3, straipsniu pakeitimo ir istatymo papildymo 5 straipsniu ir priedu įstatymas $2021 \mathrm{~m}$. sausio $14 \mathrm{~d}$. Nr.XIV-170. Vilnius. TAR, 2021-01-20, Nr. 909, 2 straipsnio pakeitimas, 7 dalis [The Law of Amendment of Article 5 and Supplementation of the Act and Annex to the Law of 2021 January 14 No. XIV-170 of the Law of the Republic of Lithuania on Social Services No. X-493 1,2,3,. Vilnius. TAR, 2021-01-20, no. 909, amendment to Article 2, part 7].

Lietuvos Respublikos socialinès apsaugos ir darbo ministro įsakymas „Dél Akredituotos vaiku dienos socialines priežiūros teikimo reikalavimų ir rekomendacijų patvirtinimo“ $2020 \mathrm{~m}$. liepos 10 d. Nr. A1-658. (2020). Prieiga internete: https://e-seimas.lrs.lt/portal/legalAct/lt/ TAD/556bd111c2e511eaae0db016672cba9c [Order of the Minister of Social Security and Labor of the Republic of Lithuania "Regarding approval of social supervisory requirements and recommendations of accredited children's day "July 10 No. A1-658. (2020)]. Access online: https://e-seimas.1rs.lt/portal/legalAct/lt/TAD/556bd111c2e511eaae0db016672cba9c

Paluckaitè, U. \& Žardeckaitè-Matulaitienè, K. (2019). The importance of emotions and personal characteristics on adolescents' risky photo-disclosure online. European proceedings of social \& behavioural sciences, 72, 407-417.

Ramsey, L. R. \& Horan, A. L. (2018). Picture this: Women's self-sexualization in photos on social media. Personality and Individual Differences, 133, 85-90.

O'Reilly, M. \& Levine, D. (2020). Applying a 'digital ethics of care' philosophy to understand adolescents' sense of responsibility on social media. Pastoral Care in Education: An International Journal of Personal, Social and Emotional Development, 2, 91-107. Access online: https://doi.org/10.1080/02643944.2020.1774635

Steijn, W. M. P. (2014). A Developmental Perspective Regarding the Behaviour of Adolescents, Young Adults, and Adults on Social Network Sites. Cyberpsychology: Journal of Psychosocial Research on Cyberspace, 8 (2), 9-18.

Schilder, J. D., Marjolein, B. Brusselaers, J. \& Bogaerts, S. (2016). The Effectiveness of an Intervention to Promote Awareness and Reduce Online Risk Behavior in Early Adolescence. J Youth Adolescence, 45, 286-300. 
Steinfeld, N. (2020). Parental mediation of adolescent Internet use: Combining strategies to promote awareness, autonomy and self-regulation in preparing youth for life on the web. Education and Information Technologies, 26(3), 1897-1920.

Access online: doi.org/10.1007/s10639-020-10342-w

Strauss, A. \& Corbin, J. (1990). Basic of Qualitative Research. Grounded Theory Procedures and Techniques. SAGE Publications.

Williams, A. L. \& Merten, M. J. (2009). Adolescents' online social networking following the death of a peer. Journal of Adolescent Research, 24 (1), 67-90.

Žydžiūnaitè, V. (2016). Metodologiniai svarstymai apie grindžiamosios teorijos ir veiklos tyrimo derinimo galimybes. Pedagogika, 122(2), 141-161 [Methodological considerations about the possibilities of combining the underlying theory and activity research. Pedagogy, 122 (2), 141-161].

Žydžiūnaite, V. (2019). Grindžiamoji teorija ir kiti kokybinio tyrimo metodai: svarstymai apie metodų esmes, panašumus ir skirtumus. In: B. Švedaitė-Sakalauskė (red.), Tirti pagal grindžiamaja teorija (p. 37-80). Vilnius: Vilniaus universiteto leidykla [Grounded theory and other methods of qualitative research: considerations about the essence and similarities of the methods and differences. In: B. Švedaitè-Sakalauskè (ed.), Research referring to the underlying theory (pp. 37-80). Vilnius: Vilnius: University publishing house].

\title{
Vaikų dienos centro specialistų veiklos pokyčiai, siekiant paauglių mergaičių atsakingumo interneto socialiniuose tinkluose
}

\author{
Lilia Žukauskiené ${ }^{1}$, Ilona Klanienè ${ }^{2}$, Rasa Skališiene ${ }^{3}$
}

$1 \quad$ Klaipedos universitetas, Socialinių ir humanitarinių mokslų fakultetas, Pedagogikos katedra, S. Neries g. 5, 92227

Klaipèda, lilia.zukauskiene@gmail.com

2. Klaipedos universitetas, Socialinių ir humanitarinių mokslų fakultetas, Pedagogikos katedra, S. Neries g. 5, 92227 Klaipèda, ilona.klaniene@ku.lt

3 Klaipedos universitetas, Socialinių ir humanitarinių mokslų fakultetas, Pedagogikos katedra, S. Neries g. 5, 92227

Klaipèda, rasa.jokubaite@gmail.com

\section{Santrauka}

Lietuvoje socialines rizikas patiriančių šeimų vaikai, stokojantys palaikymo ir ugdymo, gali gauti pagalbą Vaikų dienos centruose (VDC). Socialiniai darbuotojai ir socialiniai pedagogai teikia vaikams socialines paslaugas, organizuoja ugdymą. Viena veiklos sričių yra paauglių veikimo interneto socialiniuose tinkluose problemų identifikavimas, elgesio stebejjimas, jo koregavimas, pagalba, formuojantis atsakingo elgesio virtualioje erdveje modelị. 
Tyrimo tikslas - suprasti VDC specialistų veiklos pokyčius siekiant mergaičių atsakingo veikimo interneto socialiniuose tinkluose. Tyrimu siekiama atskleisti specialistų veiklos pokyčių priežastis; išskirti kontekstinius, ịsiterpiančius veiklos pokyčių veiksnius; išryškinti veiksmų strategijas mergaičių atsakingumo IST srityje; identifikuoti veiklos pasekmes. Atliktas kokybinis tyrimas remiasi grindžiamosios teorijos metodologijos A. Strauss, J. Corbin (1990) versija. Tyrime dalyvavo 14 specialistų iš įvairių Lietuvos miestų ir rajonų VDC, turejję darbo su paaugliais IST tema patirties.

Tyrimo rezultatai: VDC specialistus keisti veiklą skatina nerimas dèl mergaičių noro pernelyg laisvai, bet neatsakingai veikti IST, centro taisyklių nepaisymas ir kt. Išryškèjo tokie kontekstiniai veiksniai kaip virtualios erdvės prieinamumas paauglèms, skirtingos jų patirtys IST. Paauglių maištavimas, VDC veiklų prioritetų skirtybės, riboti ištekliai išryškẻjo kaip įsiterpiančios sąlygos. Specialistai imasi tokių edukacinių veiksmų strategijų: palaiko mergaičių tėvus ir ịtraukia juos ị VDC gyvenimą, reflektuoja savo veiklą, skatina patirtinị mokymąsi, kūrybiškai atskleidžia paauglems atsakingų veiksmų IST pasirinkimus/alternatyvas.

Esminiai žodžiai: Vaiku dienos centras, Vaiku dienos centro specialistai (socialiniai darbuotojai ir socialiniai pedagogai), veiklos pokyčiai, paauglès mergaités, atsakingumas interneto socialiniuose tinkluose.

Gauta 20210407 / Received 07042021

Priimta 20210927 / Accepted 27092021 